The one of the most perspective territories of Ukraine for the freshwater protists study is Ukrainian Polissya with different type of water reservoirs. Thus purposeful ekologic-faunistic research of testaceans of Zhitomir Polessya is not conducted, what coused the special researches of this group for a region.

There are found of 3 species of testate amoebae new for Ukraine: Nebela bigibbosa Penard, 1890, N. dentistoma Penard, 1890, N. vitraea Penard, 1899.

The arcticle contains the original descriptions and short ecological descriptions feature of investigated taxa. Species descriptions are written on the basis of own observation and publiched data.

Key words: testate amoebae, taxa, Nebela, fauna, sphagnum, Zhytomir Polessje.

Стаття надійшла до редколегії 26.10.2015 p.

УДК 504.45:612.118

Ольга Бедункова

\title{
Морфометричний гомеостаз іхтіоценозу та екологічний статус малої річки Рівненської області
}

Проведено аналіз флуктуючої асиметрії представників іхтіоценозу малої річки Устя, що засвідчив: у риб зі створів із мінімальним антропогенним навантаженням стабільність розвитку була вищою, ніж в особин у межах уробекосистеми. Найвищий морфометричний гомеостаз мав карась, найнижчий - плітка та верховодка, сягаючи різниці між створами 47,9 та 60,9 \%. Найтіснішими виявилися залежності від рівня забруднення поверхневих вод і дисперсією асиметрії кількості зябрових тичинок у першій зябровій дузі $\left(\mathrm{R}^{2}=0,735\right)$, а також морфометричний гомеостаз плітки $\left(\mathrm{R}^{2}=0,808\right)$ та верховодки $\left(\mathrm{R}^{2}=0,673\right)$.

Ключові слова: іхтіоценоз, флуктуюча асиметрія, якість поверхневих вод.

Постановка наукової проблеми та ії значення. Сучасні дослідження стану гідроекосистем Рівненської області свідчать, що в їхніх басейнах знизилася стійкість природних ландшафтів, порушилася рівновага в екосистемах, простежується повсюдне погіршення якості поверхневих вод, значна частина річок утратила природну самоочисну здатність [1]. Зокрема, антропогенне навантаження на басейн малої річки Устя визначається розміщеними на іiї берегах промисловими підприємствами Рівненського й Здолбунівського районів. Уздовж русла в межах населених пунктів відзначається побутове забруднення. Річка зарегульована водосховищами, у верхній та нижній течії заплава меліорована. У літньо-осінню та зимову межень у поверхневих водах відзначено зменшення концентрації розчиненого кисню, погіршення умов розкладу органічних речовин і їх інтенсивне накопичення, збільшення концентрації азоту, фосфору, різноманітних металів, хлорорганічних сполук тощо [2]. У результаті відбувається збідніння видового складу іхтіоценозу річки та погіршення фізіологічного стану особин [3].

Аналіз досліджень проблеми. Численні дослідження свідчать, що при появі будь-якого стресового фактора у водному середовищі відчутно зростають відхилення від білатеральної симетрії в будові різних морфологічних структур риб $[4,5]$. Уважається, що підвищення показника флуктуючої асиметрії (ФА) на груповому рівні вказує на дестабілізацію процесу розвитку в популяції, від стану якої, нарешті, залежить як збереження окремих видів, так і нормальне функціонування екосистеми в цілому $[6,7]$.

Так, під час аналізу вибірок уклейки Alburnis alburnis із місць із різним рівнем радіоактивного забруднення 3'ясовано, що найбільш показовою ознакою впливу негативного фактора $є$ саме асимерія меристичних ознак при тому, що морфометричні ознаки не мали такої чутливості [4].

Антропогенні ефекти на ФА риб відзначено й у гольяна Phoxinus phoxinus річки, на території басейну якої здійснюється розробка нафтогазових родовищ, що призводить до ії хімічного забруднення. При цьому найвищою виявилася залежність від рівня забруднення поверхневих вод $(\mathrm{r}=0,69)$ за дисперсією по асиметрії для такої меристичної ознаки, як кількість променів у грудних плавцях [8].

(C) Бєдункова О., 2015 
Загалом аналіз доступних нам робіт із вивчення ФА риб доводить: рівні ФА є прямим відображенням морфометричного гомеостазу іхтіоценозів, який $є$ підставою, щоб стверджувати і про гетерогенність популяцій риб, і про механізми зворотних реакцій рибного населення гідроекосистем на різні рівні антропогенного впливу.

Мета досліджень - 3'ясування відгуку іхтіоценозу малої річки Устя на різні рівні антропогенного впливу, а завдання - визначення рівнів флуктуючої асиметрії парних меристичних ознак риб і виявлення залежності дисперсії асиметрії від якості поверхневих вод.

Виклад основного матеріалу й обгрунтування отриманих результатів дослідження. Контрольні облови риби проводили в період літньо-осінньої межені 2014 р. на малій річці Устя, долина якої лежить у нижній частині Волинського Полісся, у межах Рівненського лесового плато, у створах із різним рівнем антропогенного навантаження: створ № 1 - поблизу с. Івачків, верхів’я річки (природний фон) - на відстані 65 км від гирла; створ № 2 - у межах міста Рівне (вплив скиду стічних вод), відстань від гирла - 25-27 км; створ № 3 - у межах смт Оржів (контрольний пункт) - 0,7 км від гирла.

Морфометричні проміри здійснювали для шести видів риб, які виявилися найбільш масовими представниками іхтіоценозу річки: лящ Abramis brama (Linnaeus, 1758) - лімно-фітофіл, бентофаг; карась сріблястий Carassius auratus (Linnaeus, 1758) - лімно-фітофіл, фітобентофаг; окунь річковий Perca fluviatilis (Linnaeus, 1758) - лімнофітофіл, іхтіобентофаг; плітка Rutilus rutilus (Linnaeus, 1758) лімно-фітофіл, еврифаг; краснопірка Scardinius erythrophthalmus (Linnaeus, 1758) - лімнофітофіл, еврифаг; верховодка Alburnus alburnus (Linnaeus, 1758) - фітофіл, еврифаг.

Морфометричний гомеостаз, який відображає стабільність розвитку риб та дає змогу отримати уявлення про умови, у яких перебував організм на ранніх стадіях онтогенезу, оцінювали за показником флуктуючої асиметрії (ФА). Як показник асиметрії для міжпопуляційного порівняння використовували середню частоту асиметричного прояву (ЧАП) на ознаку, яку розраховували як відношення числа ознак, що виявляють асиметрію, до загальної кількості врахованих ознак [9].

Оцінку відхилення стабільності розвитку від умовно нормального стану проводили за відповідною шкалою згаданої методики (табл. 1).

Таблиия 1

Шкала для оцінки відхилень стану риб від умов норми [9]

\begin{tabular}{|c|c|l|}
\hline Бал & $\begin{array}{c}\text { Значення показника стабільності } \\
\text { розвитку ЧАП }\end{array}$ & \multicolumn{1}{c|}{ Якість середовища } \\
\hline 1 & $<0,30$ & $\bullet$ умовно нормальне \\
\hline 2 & $0,3-0,34$ & $\bullet$ початкові (незначні) відхилення від норми \\
\hline 3 & $0,35-0,39$ & $\bullet$ середній рівень відхилень від норми \\
\hline 4 & $0,40-0,44$ & $\bullet$ суттєві (значні) відхилення від норми \\
\hline 5 & $0,45 \mathrm{та}>$ & $\bullet$ критичний стан \\
\hline
\end{tabular}

Усі проміри проводили безпосередньо після вилову риби, прижиттєво, після чого особин знову випускали в річки.

Флуктуючу асиметрію оцінювали для дев’яти білатеральних (парних) меристичних ознак: кількість променів у грудних $(P)$ і черевних $(V)$ плавцях; кількість зябрових тичинок на першій зябровій дузі $(s p . b r$.$) ; кількість пелюсток у зябровій перетинці (f.br.); кількість лусок у бічній лінії (jj); кількість$ лусок із сенсорними канальцями (jj.sk); кількість рядів лусок над (squ.l) і під (squ.2) бічною лінією; кількість лусок із боку хвостового плавця (squ.pl).

Усереднені результати проведених промірів меристичних ознак для всіх видів риб щодо окремих створів та їх статистичний обробіток наведено в таблицях 2-4.

Аналіз таблиць 2-4 дає підставу відзначити, що статистично достовірними $(\mathrm{P} \leq 0,05 ; \mathrm{P} \leq 0,01)$ за критерієм Стьюдента були результати визначень насамперед для таких видів риб, як плітка, верховодка, краснопірка, окунь і лящ. Достовірність різниці меристичних промірів карася, як правило, не підтверджувалася відносно контрольних значень. Можна припустити, що, оскільки карась сріблястий не $є$ характерним представником аборигенної іхтіофауни Волинського Полісся [3], то адапто- 
Рівні флуктуючої асиметрії парних меристичних ознак представників іхтіофауни р. Устя (створ №1)

\begin{tabular}{|c|c|c|c|c|c|c|c|c|c|c|c|c|c|c|c|c|c|c|c|}
\hline \multirow{2}{*}{\multicolumn{2}{|c|}{$\begin{array}{l}\text { Ознака } \\
\text { Значення* }\end{array}$}} & \multicolumn{3}{|c|}{$\begin{array}{c}\text { Верховодка } \\
(\mathrm{n}=27 \text { екз. })\end{array}$} & \multicolumn{3}{|c|}{$\begin{array}{c}\text { Плітка } \\
(\mathrm{n}=24 \text { екз. }) \\
\end{array}$} & \multicolumn{3}{|c|}{$\begin{array}{c}\begin{array}{c}\text { Краснопірка } \\
(\mathbf{n}=25 \text { екз. })\end{array} \\
\end{array}$} & \multicolumn{3}{|c|}{$\begin{array}{l}\text { Окунь річковий } \\
\text { (n= 21 екз.) }\end{array}$} & \multicolumn{3}{|c|}{$\begin{array}{c}\text { Карась сріблстий } \\
(\mathrm{n}=26 \text { екз.) }\end{array}$} & \multicolumn{3}{|c|}{$\begin{array}{c}\text { Лящ } \\
(\mathrm{n}=\mathbf{2 3} \text { екз. })\end{array}$} \\
\hline & & $\mathbf{R}$ & $\mathbf{L}$ & $\mathbf{A}$ & $\mathbf{R}$ & $\mathbf{L}$ & $\mathbf{A}$ & $\mathbf{R}$ & $\mathbf{L}$ & $\mathbf{A}$ & $\mathbf{R}$ & $\mathbf{L}$ & $\mathbf{A}$ & $\mathbf{R}$ & $\mathbf{L}$ & $\mathbf{A}$ & $\mathbf{R}$ & $\mathbf{L}$ & $\mathbf{A}$ \\
\hline \multirow{3}{*}{$P$} & $\mathrm{M}$ & 10,6 & 10,7 & \multirow{3}{*}{15} & 16,7 & 16,5 & \multirow{3}{*}{11} & 10,5 & 10,6 & \multirow{3}{*}{8} & 13,8 & 13,7 & \multirow{3}{*}{10} & 12,8 & 12,8 & \multirow{3}{*}{7} & 16,5 & 16,6 & \multirow{3}{*}{11} \\
\hline & $\pm \mathrm{m}$ & 0,62 & 0,64 & & 0,57 & 0,72 & & $\begin{array}{l}0,59 \\
\end{array}$ & 0,5 & & 0,51 & 0,48 & & 0,37 & 0,40 & & 0,51 & 0,51 & \\
\hline & $\mathrm{P} \leq$ & 0,05 & 0,05 & & 0,05 & 0,05 & & 0,05 & 0,05 & & - & 0,05 & & 0,01 & 0,01 & & 0,05 & 0,05 & \\
\hline \multirow{3}{*}{ V } & $\mathrm{M}$ & 8,2 & 8,0 & \multirow{3}{*}{11} & 8,8 & 8,6 & \multirow{3}{*}{7} & 13,7 & 13,6 & \multirow{3}{*}{9} & 10,6 & 10,6 & \multirow{3}{*}{7} & 11,8 & 11,8 & \multirow{3}{*}{10} & 8,8 & 8,7 & \multirow{3}{*}{9} \\
\hline & $\pm \mathrm{m}$ & 0,43 & 0,61 & & 0,44 & 0,5 & & 0,48 & 0,49 & & 0,51 & 0,49 & & 0,40 & 0,40 & & 0,42 & 0,45 & \\
\hline & $\mathrm{P} \leq$ & 0,05 & 0,05 & & 0,05 & 0,05 & & 0,05 & 0,05 & & 0,05 & 0,05 & & 0,01 & 0,01 & & 0,01 & 0,05 & \\
\hline \multirow{3}{*}{$s p . b r$} & $\mathrm{M}$ & 45,2 & 45,3 & \multirow{3}{*}{21} & 11,4 & 11,3 & \multirow{3}{*}{14} & 45,4 & 45,0 & \multirow{3}{*}{19} & 51,3 & 51,2 & & 52,1 & 52,1 & & 23,3 & 23,2 & \\
\hline & $\pm \mathrm{m}$ & 0,82 & 0,71 & & 0,65 & 0,64 & & 0,7 & 0,76 & & 0,66 & 0,7 & 14 & 0,61 & 0,59 & 7 & 0,77 & 0,72 & 15 \\
\hline & $\mathrm{P} \leq$ & 0,05 & 0,05 & & 0,05 & 0,05 & & 0,05 & 0,05 & & 0,05 & 0,05 & & 0,05 & 0,05 & & 0,05 & 0,05 & \\
\hline & $\mathrm{M}$ & 9,7 & 9,6 & & 2,8 & 2,8 & & 9,8 & 9,6 & & 11,8 & 11,6 & & 12,8 & 12,8 & & 2,7 & 2,7 & \\
\hline f.br. & $\pm \mathrm{m}$ & 0,5 & 0,6 & 13 & 0,42 & 0,44 & 9 & 0,44 & 0,49 & 9 & 0,40 & 0,50 & 8 & 0,37 & 0,40 & 5 & 0,47 & 0,49 & 11 \\
\hline & $\mathrm{P} \leq$ & 0,05 & 0,05 & & 0,01 & 0,05 & & 0,05 & 0,05 & & 0,01 & 0,05 & & 0,01 & 0,01 & & 0,05 & 0,05 & \\
\hline & $\mathrm{M}$ & 45,6 & 45,6 & & 41,7 & 41,7 & & 42,8 & 42,7 & & 67,8 & 67,7 & & 40,9 & 40,9 & & 52,8 & 52,7 & \\
\hline$j j$ & $\pm \mathrm{m}$ & 0,57 & 0,49 & 11 & 0,48 & 0,46 & 12 & 0,5 & 0,56 & 12 & 0,4 & 0,46 & 6 & 0,33 & 0,27 & 3 & 0,39 & 0,47 & 9 \\
\hline & $\mathrm{P} \leq$ & 0,05 & 0,05 & & 0,05 & 0,05 & & - & 0,05 & & 0,01 & 0,05 & & - & - & & 0,05 & 0,05 & \\
\hline & $\bar{M}$ & 18,7 & 18,7 & & 40,8 & 40,8 & & 37,7 & 37,8 & & 60,7 & 60,6 & & 38,9 & 38,9 & & 52,7 & 52,7 & \\
\hline$j j_{c k}$ & $\pm \mathrm{m}$ & 0,53 & 0,47 & 5 & 0,44 & 0,42 & 11 & 0,48 & 0,44 & 10 & 0,46 & 0,50 & 8 & 0,19 & 0,33 & 4 & 0,49 & 0,45 & 7 \\
\hline & $\mathrm{P} \leq$ & 0,05 & 0,05 & & 0,05 & 0,01 & & 0,05 & 0,05 & & 0,05 & 0,05 & & - & - & & 0,05 & 0,05 & \\
\hline & $\bar{M}$ & 10,7 & 10,9 & & 6,9 & 6,9 & & 9,8 & 9,7 & & 7,9 & 7,9 & & $\begin{array}{l}8,9 \\
\end{array}$ & 8,9 & & 9,0 & 9,0 & \\
\hline$s q u \cdot{ }_{\cdot}$ & $\pm \mathrm{m}$ & 0,45 & 0,36 & 5 & 0,34 & 0,2 & 4 & 0,44 & 0,48 & 8 & 0,22 & 0,36 & 4 & 0,19 & 0,27 & 3 & 0,0 & 0,0 & 0 \\
\hline & $\mathrm{P} \leq$ & 0,05 & 0,05 & & - & - & & 0,05 & 0,05 & & - & - & & - & - & & - & - & \\
\hline & $\mathrm{M}$ & 3,8 & 3,7 & & 3,9 & 3,9 & & 3,9 & 3,8 & & 4,9 & 4,9 & & 4,8 & 4,8 & & 4,0 & 4,0 & \\
\hline$s q u_{\cdot 2}$ & $\pm \mathrm{m}$ & 0,4 & 0,48 & 5 & 0,2 & 0,3 & 3 & 0,28 & 0,37 & 7 & 0,30 & 0,30 & 5 & 0,37 & 0,37 & 2 & 0,0 & 0,0 & 0 \\
\hline & $\mathrm{P} \leq$ & 0,05 & 0,05 & & - & - & & - & 0,01 & & - & - & & 0,01 & 0,01 & & - & - & \\
\hline & $\mathrm{M}$ & 11,8 & 11,7 & & 9,9 & 9,8 & & 12,9 & 12,9 & & 11,9 & 11,9 & & 11,8 & 11,8 & & 12,9 & 12,8 & \\
\hline squ.pl & $\pm \mathrm{m}$ & 0,40 & 0,47 & 3 & 0,3 & 0,4 & 2 & 0,29 & 0,38 & 5 & 0,32 & 0,27 & 5 & 0,37 & 0,37 & 0 & 0,28 & 0,38 & 6 \\
\hline & $\mathrm{P} \leq$ & 0,05 & 0,05 & & - & 0,01 & & - & 0,01 & & - & - & & 0,01 & 0,01 & & - & 0,01 & \\
\hline
\end{tabular}

*Примітка. $\mathrm{R}$ - величина ознак із правої сторони тіла риб; L - величина ознак із лівої сторони тіла риб; А - кількість асиметричних проявів ознаки у вибірці; М - середня величина ознаки для вибірки, см; $\pm \mathrm{m}$ - середньоквадратичне відхилення; Р $\leq-$ рівень помилки за критерієм Стьюдента [10]. 
Рівні флуктуючої асиметрії парних меристичних ознак представників іхтіофауни р. Устя (створ № 2)

\begin{tabular}{|c|c|c|c|c|c|c|c|c|c|c|c|c|c|c|c|c|c|c|c|}
\hline \multirow{2}{*}{\multicolumn{2}{|c|}{ Ознака }} & \multicolumn{3}{|c|}{$\begin{array}{c}\text { Верховодка } \\
\text { (n= 27 екз.) }\end{array}$} & \multicolumn{3}{|c|}{$\begin{array}{c}\text { Плітка } \\
\text { (n= 22 екз.) }\end{array}$} & \multicolumn{3}{|c|}{$\begin{array}{c}\text { Краснопірка } \\
(\mathbf{n}=35 \text { екз.) }\end{array}$} & \multicolumn{3}{|c|}{$\begin{array}{c}\text { Окунь річковий } \\
\text { (n= 32 екз.) }\end{array}$} & \multicolumn{3}{|c|}{$\begin{array}{c}\text { Карась сріблстий } \\
(\mathrm{n}=\mathbf{3 8} \text { екз.) }\end{array}$} & \multicolumn{3}{|c|}{$\begin{array}{c}\text { Лящ } \\
\text { (n= 23 екз.) }\end{array}$} \\
\hline & & $\mathbf{R}$ & $\mathbf{L}$ & $\mathbf{A}$ & $\mathbf{R}$ & $\mathbf{L}$ & $\mathbf{A}$ & $\mathbf{R}$ & $\mathbf{L}$ & $\mathbf{A}$ & $\mathbf{R}$ & $\mathbf{L}$ & $\mathbf{A}$ & $\mathbf{R}$ & $\mathbf{L}$ & $\mathbf{A}$ & $\mathbf{R}$ & $\mathbf{L}$ & $\mathbf{A}$ \\
\hline \multirow{3}{*}{$P$} & $\mathrm{M}$ & 10,9 & 11,0 & \multirow{3}{*}{12} & 16,4 & 16,8 & \multirow{3}{*}{18} & 10,4 & 10,5 & \multirow{3}{*}{21} & 13,5 & 13,3 & \multirow{3}{*}{21} & 12,6 & 12,6 & \multirow{3}{*}{14} & 16,7 & 16,7 & \multirow{3}{*}{13} \\
\hline & $\pm \mathrm{m}$ & 0,62 & 0,48 & & 0,53 & 0,57 & & 0,8 & 0,66 & & 0,62 & 0,65 & & 0,5 & 0,49 & & 0,54 & 0,45 & \\
\hline & $\mathrm{P} \leq$ & 0,05 & 0,05 & & 0,05 & 0,05 & & 0,05 & 0,05 & & 0,05 & 0,05 & & 0,05 & 0,05 & & 0,01 & 0,05 & \\
\hline \multirow{3}{*}{ V } & $\mathrm{M}$ & 8,4 & 8,4 & \multirow{3}{*}{13} & 8,9 & 8,6 & \multirow{3}{*}{14} & 13,5 & 13,5 & \multirow{3}{*}{18} & 10,8 & 10,9 & \multirow{3}{*}{19} & 11,7 & 11,6 & \multirow{3}{*}{15} & 8,6 & 8,7 & \multirow{3}{*}{11} \\
\hline & $\pm \mathrm{m}$ & 0,75 & 0,69 & & 0,51 & 0,47 & & 0,74 & 0,66 & & 0,91 & 0,91 & & 0,49 & 0,46 & & 0,59 & 0,56 & \\
\hline & $\mathrm{P} \leq$ & 0,05 & 0,05 & & 0,05 & 0,05 & & 0,05 & 0,05 & & 0,05 & 0,05 & & 0,01 & - & & 0,05 & 0,01 & \\
\hline \multirow{3}{*}{$s p . b r}$. & $\mathrm{M}$ & 45,4 & 45,2 & \multirow{3}{*}{21} & 11,4 & 11,1 & \multirow{3}{*}{26} & 45,3 & 45,5 & \multirow{3}{*}{23} & 52,2 & 52,3 & & 52,2 & 52,1 & & 24,3 & 24,2 & \\
\hline & $\pm \mathrm{m}$ & 0,75 & 0,89 & & 0,91 & 0,67 & & 0,77 & 0,66 & & 0,83 & 0,96 & 22 & 0,79 & 0,76 & 16 & 0,82 & 0,67 & 16 \\
\hline & $\mathrm{P} \leq$ & 0,05 & 0,05 & & 0,05 & 0,05 & & 0,05 & 0,05 & & 0,05 & 0,05 & & 0,05 & 0,05 & & 0,05 & 0,05 & \\
\hline & $\mathrm{M}$ & 13,9 & 14,0 & & 2,4 & 2,5 & & 9,7 & 9,7 & & 11,8 & 11,8 & & 12,7 & 12,7 & & 12,9 & 12,8 & \\
\hline f.br. & $\pm \mathrm{m}$ & 0,27 & 0,0 & 3 & 0,53 & 0,58 & 16 & 0,46 & 0,47 & 5 & 0,42 & 0,42 & 4 & 0,45 & 0,45 & 8 & 0,34 & 0,39 & 7 \\
\hline & $\mathrm{P} \leq$ & 0,05 & 0,05 & & 0,05 & 0,05 & & 0,05 & 0,05 & & 0,05 & 0,05 & & - & - & & - & 0,01 & \\
\hline & $\bar{M}$ & 46,8 & 46,7 & & 41,7 & 41,6 & & 45,7 & 45,7 & & 41,6 & 41,7 & & 40,5 & 40,6 & & 38,7 & 38,6 & \\
\hline$i j$ & $\pm \mathrm{m}$ & 0,51 & 0,53 & 17 & 0,45 & 0,43 & 15 & 0,73 & 0,70 & 17 & 0,49 & 0,52 & 17 & 0,51 & 0,50 & 17 & 0,54 & 0,51 & 10 \\
\hline & $\mathrm{P} \leq$ & 0,05 & 0,05 & & 0,05 & 0,05 & & 0,05 & 0,05 & & 0,05 & 0,05 & & 0,01 & 0,01 & & 0,01 & 0,01 & \\
\hline & $\mathrm{M}$ & 44,5 & 44,5 & & 40,4 & 40,8 & & 44,6 & 44,6 & & 39,8 & 39,8 & & 38,7 & 38,6 & & 38,7 & 38,5 & \\
\hline$j j_{c k}$ & $\pm \mathrm{m}$ & 0,7 & 0,6 & 19 & 0,44 & 0,49 & 14 & 0,61 & 0,69 & 16 & 0,49 & 0,44 & 13 & 0,48 & 0,49 & 7 & 0,57 & 0,59 & 12 \\
\hline & $\mathrm{P} \leq$ & 0,05 & 0,05 & & 0,05 & 0,05 & & 0,05 & 0,05 & & 0,05 & 0,05 & & 0,01 & 0,01 & & 0,05 & 0,05 & \\
\hline & $\mathrm{M}$ & 10,9 & 10,9 & & 6,7 & 6,9 & & 10,6 & 10,6 & & 8,8 & 8,8 & & $\begin{array}{l}8,7 \\
\end{array}$ & 8,7 & & $\begin{array}{l}8,7 \\
\end{array}$ & 8,9 & \\
\hline$s q u_{.1}$ & $\pm \mathrm{m}$ & 0,32 & 0,27 & 8 & 0,34 & 0,40 & 12 & 0,6 & 0,55 & 7 & 0,4 & 0,44 & 8 & 0,52 & 0,46 & 9 & 0,56 & 0,29 & 7 \\
\hline & $\mathrm{P} \leq$ & 0,05 & 0,05 & & 0,05 & 0,05 & & 0,55 & 0,55 & & 0,05 & 0,05 & & - & - & & 0,01 & - & \\
\hline & $\mathrm{M}$ & 3,8 & 3,8 & & 3,9 & 3,8 & & 3,6 & 3,7 & & 5,8 & 5,7 & & 4,7 & 4,7 & & 3,9 & 3,9 & \\
\hline$s q u_{2}$ & $\pm \mathrm{m}$ & 0,42 & 0,58 & 9 & 0,34 & 0,37 & 8 & 0,6 & 0,59 & 9 & 0,51 & 0,46 & 9 & 0,45 & 0,48 & 5 & 0,29 & 0,34 & 6 \\
\hline & $\mathrm{P} \leq$ & 0,05 & 0,05 & & 0,05 & 0,05 & & 0,05 & 0,05 & & 0,05 & 0,05 & & - & - & & - & - & \\
\hline & $\bar{M}$ & 10,7 & 10,7 & & 10,8 & 10,9 & & 10,7 & 10,7 & & 12,7 & 12,8 & & 11,7 & 11,7 & & 12,8 & 12,8 & \\
\hline squ.pl & $\pm \mathrm{m}$ & 0,73 & 0,45 & 10 & 0,35 & 0,32 & 7 & 0,46 & 0,51 & 6 & 0,54 & 0,44 & 10 & 0,48 & 0,46 & 4 & 0,39 & 0,42 & 9 \\
\hline & $\mathrm{P} \leq$ & 0,05 & 0,05 & & 0,05 & 0,05 & & 0,05 & 0,05 & & 0,05 & 0,05 & & - & - & & 0,01 & 0,01 & \\
\hline
\end{tabular}

*Примітка. $\mathrm{R}$ - величина ознак із правої сторони тіла риб; $\mathrm{L}$ - величина ознак із лівої сторони тіла риб; А - кількість асиметричних проявів ознаки у вибірці; М - середня величина ознаки для вибірки, см; $\pm \mathrm{m}$ - середньоквадратичне відхилення; Р $\leq-$ рівень помилки за критерієм Стьюдента [10]. 
Рівні флуктуючої асиметрії парних меристичних ознак представників іхтіофауни р. Устя (створ №3)

\begin{tabular}{|c|c|c|c|c|c|c|c|c|c|c|c|c|c|c|c|c|c|c|c|}
\hline \multirow{2}{*}{\multicolumn{2}{|c|}{$\begin{array}{l}\text { Ознаки } \\
\text { Значення* }\end{array}$}} & \multicolumn{3}{|c|}{$\begin{array}{c}\begin{array}{c}\text { Верховодка } \\
(\mathrm{n}=25 \text { екз. })\end{array} \\
\end{array}$} & \multicolumn{3}{|c|}{$\begin{array}{c}\text { Плітка } \\
(\mathbf{n}=32 \text { екз. })\end{array}$} & \multicolumn{3}{|c|}{$\begin{array}{c}\text { Краснопірка } \\
(\mathrm{n}=\text { екз. })\end{array}$} & \multicolumn{3}{|c|}{$\begin{array}{c}\text { Окунь річковий } \\
(\mathrm{n}=\text { екз. })\end{array}$} & \multicolumn{3}{|c|}{$\begin{array}{c}\begin{array}{c}\text { Карась сріблстий } \\
\text { (n= екз.) }\end{array} \\
\end{array}$} & \multicolumn{3}{|c|}{$\begin{array}{c}\text { Лящ } \\
(\mathrm{n}=\text { екз.) }\end{array}$} \\
\hline & & $\mathbf{R}$ & $\mathbf{L}$ & $\mathbf{A}$ & $\mathbf{R}$ & $\mathbf{L}$ & $\mathbf{A}$ & $\mathbf{R}$ & $\mathbf{L}$ & $\mathbf{A}$ & $\mathbf{R}$ & $\mathbf{L}$ & $\mathbf{A}$ & $\mathbf{R}$ & $\mathbf{L}$ & $\mathbf{A}$ & $\mathbf{R}$ & $\mathbf{L}$ & $\mathbf{A}$ \\
\hline \multirow{3}{*}{$P$} & $\mathrm{M}$ & 10,6 & 10,8 & \multirow{3}{*}{9} & 16,6 & 16,5 & \multirow{3}{*}{20} & 10,7 & 10,6 & \multirow{3}{*}{17} & 13,7 & 13,7 & \multirow{3}{*}{15} & 12,9 & 12,9 & \multirow{3}{*}{8} & 16,9 & 16,8 & \multirow{3}{*}{7} \\
\hline & $\pm \mathrm{m}$ & 0,49 & 0,44 & & 0,56 & 0,57 & & 0,45 & 0,49 & & 0,48 & 0,46 & & 0,36 & 0,36 & & 0,29 & 0,43 & \\
\hline & $\mathrm{P} \leq$ & 0,05 & 0,05 & & 0,05 & 0,05 & & 0,05 & 0,05 & & 0,05 & 0,05 & & 0,01 & 0,01 & & - & 0,01 & \\
\hline \multirow{3}{*}{$V$} & $\bar{M}$ & 7,6 & 7,6 & \multirow{3}{*}{10} & 8,7 & 8,6 & \multirow{3}{*}{12} & 13,7 & 13,6 & \multirow{3}{*}{11} & 10,8 & 10,5 & \multirow{3}{*}{14} & 11,9 & 11,8 & \multirow{3}{*}{4} & 8,9 & 8,9 & \multirow{3}{*}{5} \\
\hline & $\pm \mathrm{m}$ & 0,49 & 0,49 & & 0,48 & 0,49 & & 0,48 & 0,49 & & 0,44 & 0,51 & & 0,36 & 0,42 & & 0,29 & 0,32 & \\
\hline & $\mathrm{P} \leq$ & 0,05 & 0,05 & & 0,05 & 0,05 & & 0,05 & 0,05 & & 0,05 & 0,05 & & 0,01 & 0,05 & & - & - & \\
\hline \multirow{3}{*}{ sp.br. } & $\mathrm{M}$ & 45,0 & 44,8 & \multirow{3}{*}{22} & 11,1 & 11,3 & \multirow{3}{*}{24} & 45,2 & 45,4 & \multirow{3}{*}{21} & 51,1 & 51,0 & & 52,3 & 52,3 & & 23,8 & 23,9 & \\
\hline & $\pm \mathrm{m}$ & 0,89 & 0,8 & & 0,82 & 0,74 & & 0,82 & 0,72 & & 0,83 & 0,75 & 17 & 0,81 & 0,71 & 13 & 0,5 & 0,24 & 10 \\
\hline & $\mathrm{P} \leq$ & 0,05 & 0,05 & & 0,05 & 0,05 & & 0,05 & 0,05 & & 0,05 & 0,05 & & 0,05 & 0,05 & & 0,05 & 0,05 & \\
\hline & $\mathrm{M}$ & 9,5 & 9,6 & & 2,6 & 2,5 & & 10,5 & 10,5 & & 11,5 & 11,7 & & 12,7 & 12,6 & & 2,9 & 2,8 & \\
\hline$f \cdot b r$. & $\pm \mathrm{m}$ & 0,59 & 0,58 & 18 & 0,55 & 0,57 & 14 & 0,57 & 0,64 & 16 & 0,51 & 0,48 & 11 & 0,48 & 0,50 & 10 & 0,29 & 0,43 & 7 \\
\hline & $\mathrm{P} \leq$ & 0,05 & 0,05 & & 0,05 & 0,05 & & 0,05 & 0,05 & & 0,05 & 0,05 & & 0,05 & 0,05 & & - & 0,01 & \\
\hline & $\mathrm{M}$ & 45,5 & 45,7 & & 41,8 & 41,6 & & 37,8 & 37,6 & & 68,7 & 68,6 & & 40,8 & 40,8 & & 52,9 & 52,9 & \\
\hline$j j$ & $\pm \mathrm{m}$ & 0,65 & 0,48 & 17 & 0,42 & 0,49 & 18 & 0,37 & 0,49 & 16 & 0,46 & 0,50 & 5 & 0,39 & 0,39 & 9 & 0,35 & 0,35 & 6 \\
\hline & $\mathrm{P} \leq$ & 0,05 & 0,05 & & 0,05 & 0,05 & & 0,01 & 0,05 & & 0,05 & 0,05 & & 0,01 & 0,01 & & - & - & \\
\hline & $\bar{M}$ & 18,7 & 18,7 & & 40,8 & 40,6 & & 42,8 & 42,8 & & 60,8 & 60,7 & & 38,9 & 38,8 & & 52,8 & 52,8 & \\
\hline$j j_{c k}$ & $\pm \mathrm{m}$ & 0,46 & 0,46 & 15 & 0,44 & 0,49 & 18 & 0,37 & 0,43 & 12 & 0,44 & 0,48 & 8 & 0,36 & 0,42 & 8 & 0,4 & 0,43 & 4 \\
\hline & $\mathrm{P} \leq$ & 0,05 & 0,05 & & 0,05 & 0,05 & & 0,01 & 0,05 & & 0,05 & 0,05 & & 0,01 & 0,05 & & 0,01 & 0,01 & \\
\hline & $\mathrm{M}$ & 10,9 & 10,8 & & 6,9 & 6,8 & & 9,9 & 9,9 & & 7,8 & 7,8 & & 9,0 & 8,9 & & 8,9 & 9,0 & \\
\hline$s q u_{.1}$ & $\pm \mathrm{m}$ & 0,2 & 0,44 & 7 & 0,34 & 0,40 & 10 & 0,25 & 0,34 & 4 & 0,38 & 0,38 & 4 & 0,0 & 0,32 & 4 & 0,29 & 0,0 & 2 \\
\hline & $\mathrm{P} \leq$ & - & 0,05 & & 0,05 & 0,05 & & - & 0,01 & & 0,01 & 0,01 & & - & - & & - & - & \\
\hline & $\bar{M}$ & 4,0 & 3,8 & & 3,8 & 3,9 & & 3,9 & 3,9 & & 4,9 & 4,9 & & 4,9 & 4,9 & & 3,9 & 3,9 & \\
\hline$s q u_{2}$ & $\pm \mathrm{m}$ & 0,0 & 0,41 & 5 & 0,37 & 0,34 & 7 & 0,25 & 0,3 & 5 & 0,20 & 0,28 & 3 & 0,32 & 0,2 & 3 & 0,21 & 0,35 & 2 \\
\hline & $\mathrm{P} \leq$ & - & 0,01 & & 0,05 & 0,05 & & - & - & & - & - & & - & - & & - & - & \\
\hline & $M$ & 12,0 & 11,9 & & 10,8 & 10,9 & & 12,9 & 12,9 & & 11,8 & 11,7 & & 11,9 & 11,9 & & 12,9 & 12,9 & \\
\hline squ.pl & $\pm \mathrm{m}$ & 0,0 & 0,28 & 2 & 0,37 & 0,30 & 7 & 0,25 & 0,3 & 3 & 0,42 & 0,46 & 2 & 0,19 & 0,26 & 3 & 0,29 & 0,29 & 2 \\
\hline & $\mathrm{P} \leq$ & - & - & & 0,05 & 0,05 & & - & - & & 0,05 & 0,05 & & - & - & & - & - & \\
\hline
\end{tabular}

*Примітка. $\mathrm{R}$ - величина ознак із правої сторони тіла риб; L - величина ознак із лівої сторони тіла риб; А - кількість асиметричних проявів ознаки у вибірці; M - середня величина ознаки для вибірки, $c м ; \pm \mathrm{m}$ - середньоквадратичне відхилення; Р $\leq-$ рівень помилки за критерієм Стьюдента [10]. 
ваність до місцевих умов зумовлена притаманним цьому виду високим рівнем морфологічного гомеостазу.

Якщо порівняти кількість випадків асиметричних проявів ознак у вибірках різних видів, то можна помітити, що в усіх трьох створах найбільш високі показники мали плітка (показник А - у межах від 2 до 26), краснопірка (від 3 до 23), окунь (від 2 до 22) і верховодка (від 2 до 21).

На рис. 1 відображено результати розрахунку розподілу рівнів ФА для окремих меристичних ознак досліджуваних видів риб у контрольних створах спостережень.

СТВор №1

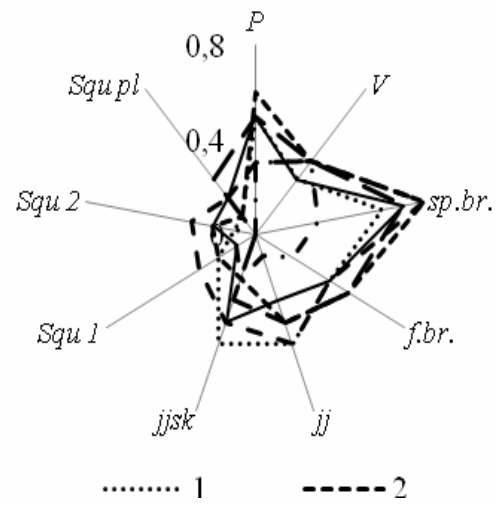

Створ №2

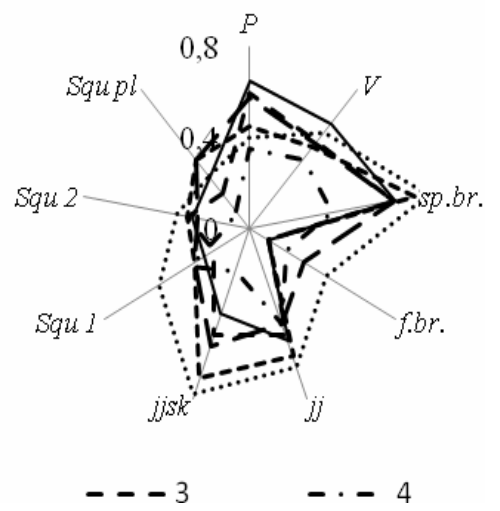

Створ №3

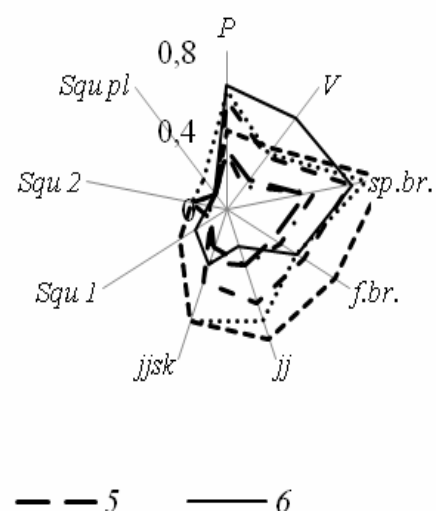

Рис. 1. Флуктуюча асиметрія білатеральних меристичних ознак іхтіоценозу р. Устя: 1 - плітка; 2 - верховодка; 3 - краснопірка; 4 - карась сріблястий; 5 -лящ; 6 - окунь звичайний

Із рис. 1 легко помітити, що в усіх створах для більшості проаналізованих видів риб, найвищі рівні ФА характерні для таких ознак, як кількість зябрових тичинок у першій зябровій дузі (sp.br), кількість променів у грудних плавцях $(P)$, а також лусок у бічній лінії (jj). У середньому ряд спадання ФА за ознаками був таким: створ №1: $s p . b r>P>f . b r .>V=j j>j j_{s k}>S q u_{1}>S q u_{2}>S q u_{p l}$; створ № 2: $s p . b r>j j>j j_{s k}>P>V>S q u_{1}>S q u_{p l}>S q u_{2}>f . b r$.; створ № 3: $s p . b r>f . b r$. $=\mathrm{P}>j j>j j_{s k}>V>S q u_{1}$ $>S q u_{2}>S q u_{p l}$.

Отримана характеристика морфологічної стабільності іхтіоценозу дала підставу судити про якість водного середовища, яку оцінювали за частотою асиметричного прояву (ЧАП) кожного виду риб із наступним усередненням значень за дослідними створами (табл. 5).

Таблиия 5

Результати оцінки відхилень представників іхтіопопуляцій р. Устя від умов норми

\begin{tabular}{|c|c|c|c|c|c|c|c|c|c|c|c|c|c|c|}
\hline \multirow{3}{*}{$\begin{array}{c}\text { № } \\
\text { створу }\end{array}$} & \multicolumn{12}{|c|}{ Вид риб } & \multirow{2}{*}{\multicolumn{2}{|c|}{$\begin{array}{c}\text { Середнє } \\
\text { для створу }\end{array}$}} \\
\hline & \multicolumn{2}{|c|}{ плітка } & \multicolumn{2}{|c|}{ верховодка } & \multicolumn{2}{|c|}{ краснопірка } & \multicolumn{2}{|c|}{ карась } & \multicolumn{2}{|c|}{ лящ } & \multicolumn{2}{|c|}{ окунь } & & \\
\hline & ЧАП & Бал $*$ & ЧАП & Бал $*$ & ЧАП & Бал* & ЧАП & Бал* & ЧАП & Бал* & ЧАП & Бал* & ЧАП & Бал* \\
\hline 1 & 0,36 & III & 0,38 & III & 0,40 & IV & 0,19 & I & 0,34 & II & 0,34 & II & 0,34 & II \\
\hline 2 & 0,53 & $\mathrm{~V}$ & 0,46 & $\mathrm{~V}$ & 0,40 & IV & 0,28 & I & 0,45 & $\mathrm{~V}$ & 0,42 & IV & 0,42 & IV \\
\hline 3 & 0,46 & $\mathrm{~V}$ & 0,48 & $\mathrm{~V}$ & 0,38 & III & 0,24 & I & 0,23 & $\mathrm{I}$ & 0,37 & III & 0,36 & III \\
\hline \multicolumn{13}{|c|}{ Середнє значення для річки } & 0,37 & III \\
\hline
\end{tabular}

*Примітка. Згідно з методикою [9]. 
Різниця в ЧАП різних видів була найпомітнішою для карася, порівняно 3 пліткою та верховодкою: для створу № 1 - 52,8 та 50 \%, відповідно; для створу № $2-52,8$ і 60,9 \%; для створу № 3 52,2 та $47,9 \%$.

Для всіх видів риб у контрольному створі №1 показник ЧАП становив величину 0,34, що характеризувала якість середовища як «початкові (незначні) зміни» та оцінювала стабільність розвитку представників іхтіоценозу на цій ділянці річки в межах II бала класифікації. У створі № 2 показник ЧАП сягнув величини 0,42, що характеризувало якість середовища як «суттєві (значні) відхилення від норми». Стабільність розвитку особин оцінюємо в межах IV балів. У створі № 3 показник ЧАП становив 0,36, що характеризувало якість середовища як «середній рівень відхилень від норми» й оцінювало стабільність розвитку особин у межах III балів.

У середньому для річки показник ЧАП становив 0,37 , що характеризувало якість водного середовища як «середній рівень відхилень від норми», а стабільність розвитку іхтіоценозу - у межах III балів.

Проведено оцінку якості поверхневих вод за відповідними категоріями [11] у контрольних створах річки Устя, що виявило: середні блокові індекси (Іе) за найгіршими значеннями ознак перебували в межах 2,7-5,4 упродовж 2010-2014 pр., що відносило води до II й III класів, характеризувало їхній стан як «добрий» і «задовільний», а ступінь чистоти - як «досить чиста» та «помірно забруднена». За середнім значенням гідрохімічних показників блокові індекси (Iе) мали значення від 2,5 до 4,3, що відносило води до II й III класів та характеризувало їхній стан як «добрий» та «задовільний», а ступінь чистоти - як «чиста-досить чиста» й «слабко забруднена».

Для виявлення залежності ФА в представників іхтіоценозу річки від рівня забруднення поверхневих вод нами використано математичну оцінку методом простого регресійного аналізу зазначених параметрів. Так, у якості інтегрального показника стабільності розвитку розраховано середню величину дисперсії ФА $\left(\sigma_{\mathrm{d}}^{2}\right)$, яка дає змогу оцінити міру відхилення варіанта від математичного очікування [10]. Отримані значення зіставлено із середніми значеннями блокових індексів поверхневих вод у контрольних створах, згідно з чим отримано величини достовірності апроксимації залежностей (табл. 6, 7).

Аналіз табл. 6 засвідчує, що найвищою виявилася залежність від рівня забруднення поверхневих вод $\left(\mathrm{R}^{2}=0,735\right)$ за дисперсією асиметрії кількості пелюсток у зябровій перетинці, що описувала поліноміальна залежність третього ступеня. Дисперсія асиметрії решти ознак і за лінійною, і за поліноміальною залежностями не підтвердила істотної тісноти зв’ язку з якістю поверхневих вод.

Табличя 6

Установлення залежності ФА на ознаку для всіх видів риб від рівня забруднення води методом простого регресійного аналізу

\begin{tabular}{|l|l|l|l|c|}
\hline \multirow{2}{*}{ Ознака } & \multicolumn{2}{|c|}{ Лінійна залежність } & \multicolumn{2}{c|}{ Поліноміальна залежність } \\
\cline { 2 - 5 } & \multicolumn{1}{|c|}{ рівняння } & \multicolumn{1}{c|}{$\mathbf{R}^{2}$} & \multicolumn{1}{c|}{ рівняння } & $\mathbf{R}^{2}$ \\
\hline$P$ & $\mathrm{y}=-0,033 \mathrm{x}+0,419$ & 0,128 & $\mathrm{y}=0,014 \mathrm{x}^{3}-0,200 \mathrm{x}^{2}+0,847 \mathrm{x}-0,789$ & 0,161 \\
\hline$V$ & $\mathrm{y}=-0,017 \mathrm{x}+0,328$ & 0,027 & $\mathrm{y}=0,064 \mathrm{x}^{3}-0,840 \mathrm{x}^{2}+3,514 \mathrm{x}-4,346$ & 0,225 \\
\hline sp.br. & $\mathrm{y}=0,030 \mathrm{x}+0,065$ & 0,212 & $\mathrm{y}=-0,043 \mathrm{x}^{3}+0,602 \mathrm{x}^{2}-2,599 \mathrm{x}+3,654$ & 0,735 \\
\hline$f . b r$. & $\mathrm{y}=0,028 \mathrm{x}+0,437$ & 0,075 & $\mathrm{y}=0,045 \mathrm{x}^{3}-0,543 \mathrm{x}^{2}+2,106 \mathrm{x}-2,091$ & 0,145 \\
\hline$j j$ & $\mathrm{y}=0,007 \mathrm{x}+0,187$ & 0,008 & $\mathrm{y}=-0,002 \mathrm{x}^{3}+0,027 \mathrm{x}^{2}-0,074 \mathrm{x}+0,258$ & 0,013 \\
\hline$j j s k$ & $\mathrm{y}=-0,023 \mathrm{x}+0,320$ & 0,069 & $\mathrm{y}=0,059 \mathrm{x}^{3}-0,752 \mathrm{x}^{2}+3,040 \mathrm{x}-3,626$ & 0,187 \\
\hline Squ 1 & $\mathrm{y}=0,011 \mathrm{x}+0,076$ & 0,017 & $\mathrm{y}=-0,009 \mathrm{x}^{3}+0,100 \mathrm{x}^{2}-0,303 \mathrm{x}+0,374$ & 0,056 \\
\hline Squ 2 & $\mathrm{y}=0,009 \mathrm{x}+0,085$ & 0,011 & $\mathrm{y}=0,011 \mathrm{x}^{3}-0,184 \mathrm{x}^{2}+0,924 \mathrm{x}-1,276$ & 0,173 \\
\hline Squ $p l$ & $\mathrm{y}=-0,017 \mathrm{x}+0,227$ & 0,047 & $\mathrm{y}=0,055 \mathrm{x}^{3}-0,744 \mathrm{x}^{2}+3,155 \mathrm{x}-4,021$ & 0,374 \\
\hline
\end{tabular}

Аналіз табл. 7 дає змогу помітити, що найвищою виявилася залежність від рівня забруднення поверхневих вод для таких видів риб, як плітка $\left(\mathrm{R}^{2}=0,808\right)$ та верховодка $\left(\mathrm{R}^{2}=0,673\right)$, що описувалися поліноміальними залежностями третього ступеня. Для решти видів риб, як за лінійною, так і за поліноміальною залежністю, дисперсія асиметрії меристичних ознак не виявила істотної тісноти зв' язку з якістю поверхневих вод. 
Установлення залежності ФА ознак окремого виду риб від рівня забруднення води методом простого регресійного аналізу

\begin{tabular}{|c|c|c|c|c|}
\hline \multirow{2}{*}{ Ознака } & \multicolumn{2}{|c|}{ Лінійна залежність } & \multicolumn{2}{|l|}{ Поліноміальна залежність } \\
\hline & рівняння & $\mathbf{R}^{2}$ & рівняння & $\mathbf{R}^{2}$ \\
\hline Плітка & $\mathrm{y}=0,989 \mathrm{x}+4,235$ & 0,021 & $y=375,5 x^{3}-339,9 x^{2}+81,42 x-0,712$ & 0,808 \\
\hline Верховодка & $y=2,514 x+3,748$ & 0,112 & $y=784,8 x^{3}-837,5 x^{2}+256,8 x-18,93$ & 0,673 \\
\hline Краснопірка & $\mathrm{y}=0,050 \mathrm{x}+0,196$ & 0,006 & $y=10,28 x^{3}-8,775 x^{2}+2,113 x+0,065$ & 0,125 \\
\hline Окунь & $y=1,657 x+4,037$ & 0,047 & $y=203,7 x^{3}-188,7 x^{2}+49,07 x+0,685$ & 0,197 \\
\hline Kapacb & $y=3,156 x+3,852$ & 0,129 & $y=-704,0 x^{3}+560,9 x^{2}-116,3 x+11,33$ & 0,161 \\
\hline Лящ & $y=2,312 x+3,988$ & 0,100 & $y=206,2 x^{3}-166,5 x^{2}+34,46 x+2,51$ & 0,143 \\
\hline
\end{tabular}

Зіставляючи якість води за відповідними категоріями та за частотою асиметричного прояву іхтіоценозу, помічаємо певні розбіжності. Так, у створі № 2 (у межах м. Рівне) середнє значення ЧАП відносило якість води до IV класу. Згідно з методикою за відповідними категоріями в цьому створі вода мала III клас якості лише за найгіршими показниками. Зазначимо, що з певних причин програма державного моніторингу за останні роки зазнала суттєвих скорочень, що певною мірою позначається на отриманні необхідного набору гідрохімічних показників для ведення коректних і повних оцінок якості поверхневих вод. Припускаємо, що саме цей факт може впливати й на величини залежностей між досліджуваними нами параметрами.

Висновки та перспективи подальшого дослідження. У риб, виловлених зі створів із мінімальним антропогенним навантаженням, морфометричний гомеостаз особин був вищим (I-III бала), ніж в особин у межах урбоекосистеми (IV-V балів). Найвищий морфометричний гомеостаз мав карась, найнижчий - плітка та верховодка, сягаючи різниці між створами 47,9 і 60,9 \%.

Найвищими виявилися залежності від рівня забруднення поверхневих вод за дисперсією асиметрії кількості зябрових тичинок у першій зябровій дузі $\left(\mathrm{R}^{2}=0,735\right)$, а також морфометричний гомеостаз плітки $\left(\mathrm{R}^{2}=0,808\right)$ і верховодки $\left(\mathrm{R}^{2}=0,673\right)$.

Виявлена невідповідність результатів оцінок екологічного статусу малої річки за різними методиками свідчить про доцільність подальших пошуків і розробок уніфікованих критеріїв оцінки стану гідроекосистем.

\section{Джерела та література}

1. Клименко О. М. Методологія покращення екологічного стану річок Західного Полісся (на прикладі р. Горинь) : монографія / О. Клименко, І. Статник ; Нац. ун-т водн. госп-ва та природокористування. Рівне : НУВГП, 2012. - 206 с.

2. Мельник В. Й. Екологічна оцінка сучасного стану якості річкових вод Рівненської області / Віра Йосипівна Мельник // Укр. геогр. журн. - 2000. - № 4. - С. 44-52.

3. Сондак В. В. До питання реабілітації умов відтворення аборигенної іхтіофауни та формування стійкості водного середовища у трансформованій річковій мережі Західного Полісся України / В. В. Сондак // Рибогосподарська наука України. - К., 2009. - № 3(9). - С. 54-60.

4. Лайус Д. Л. Флуктуирующая асимметрия и случайная фенотипическая изменчивость в популяционных исследованиях: история, достижения, проблемы, перспективы / Д. Л. Лайус [та ін.] // Вестник СанктПетербургского университета. - 2009. - № 3. - С. 98-176.

5. Виноградов К. П. Вивчення флуктуючої асиметрії річкового окуня (Perca fluviatilis L., 1758) / К. П. Виноградов [та ін.] // Збірник наукових праць Харківського національного педагогічного університету імені Г. С. Сковороди Біологія та валеологія. - 2012. - Вип. 14. - С. 9-17.

6. Van Valen L. Study of fluctuating asymmetry / L. Van Valen // Evolution. - 1962. - Vol. 16, № 2. - P. $125-146$.

7. Четвериков С. С. О некоторых моментах эволюционного процесса с точки зрения современной генетики / С. С. Четвериков // Классики советской генетики. - Л. : Наука, 1968. - С. 133-170.

8. Туманов М. Д. Оценка экологической ситуации в бассейне р. Усы (притока Печоры I порядка) после аварии нефтепровода по данным анализа флуктуирующей асимметрии / М. Д. Туманов, Ю. П. Шубин // Биологические ресурсы Белого моря и внутренних водоемов европейского Севера : тез. докл. II Междунар. конф. - Петрозаводск, 1999. - С. 64-65.

9. Захаров В. М. Здоровье среды: практика оценки. Центр экологической политики России. Центр здоровья среды / В. М. Захаров. - М., 2000. - 320 с. 
10. Прикладная статистика: исследование зависимостей : справ. изд. / под ред. С. А. Айвазян. - М. : Финансы и статистика, 1985.- 487 с.

11. Романенко В. Д. Методика экологической оценки качества поверхностных вод по соответствующим категориям / В. Д. Романенко [и др.]. - Киев : СИМВОЛ-Т, 1998. - 28 с.

Бедункова Ольга. Морфометрический гомеостаз ихтиоценоза и экологический статус малой реки Ровенской области. Анализ флуктуирующей асимметрии представителей ихтиоценоза малой реки Устья показал, что у рыб, отловленных в створах с минимальной антропогенной нагрузкой, стабильность развития была выше, чем у особей в пределах уробекосистемы. Самый высокий морфометрический гомеостаз имел карась, самый низкий - плотва и верховодка. Тесными оказались зависимости от уровня загрязнения поверхностных вод и дисперсией асимметрии количества жаберных тычинок в первой жаберной дуге $\left(\mathrm{R}^{2}=0,735\right)$, a также морфометрический гомеостаз плотвы $\left(\mathrm{R}^{2}=0,808\right)$ и верховодки $\left(\mathrm{R}^{2}=0,673\right)$. Стабильность развития ихтиоценоза и качество водной среды оценены как «средний уровень отклонений от нормы», III бала. Гидрохимические показатели свидетельствовали о переходе от II к III классу качества поверхностных вод. При этом в отдельных створах результаты оценок экологического статуса реки по использованным методикам не совпадали, что свидетельствует о необходимости разработок унифицированных критериев оценки состояния гидроэкосистем.

Ключевые слова: ихтиоценоз, флуктуирующая асимметрия, качество поверхностных вод.

Biedunkova Olga. Morphometric Ichthyocenosis Homeostasis and Ecological Status of The Small River of Rivne Region. Fluctuating asymmetry in fish that are caught in the sections of the river with minimal anthropogenic load showed that the stability of their development has been higher than that of individuals within urobekosistem. Highest morphometric homeostasis had the roach and the perched. It turned out to be closely based on the level of contamination of surface water and the dispersion of the asymmetry in the number of gill rakers of the first gill arch $\left(\mathrm{R}^{2}=0,735\right)$, and the morphometric homeostasis roach $\left(\mathrm{R}^{2}=0,808\right)$ and the perched $\left(\mathrm{R}^{2}=0,673\right)$. Stability and development ichthyocenosis water quality rated as «average deviation from the norm», III ball. Hydrochemical indicators showed the transition from II to III class quality of surface waters. At the same time, in separate alignments results of the evaluations of the ecological status of the river on the methodology used did not match. This demonstrates the need for development of standardized criteria for assessment of hydroecosistem.

Key words: ichthyocenosis, fluctuating asymmetry, surface water quality.

Стаття надійшла до редколегії 14.09.2015 p.

УДК 594.38:574.2

Алла Гарлінська

\section{Будова статевої системи молюсків підродини Physinae}

Здійснено аналіз кількісних показників статевої системи семи видів молюсків підродини Рhysinae (Physa fontinalis, Ph. adversa, Ph. skinneri, Ph. bulla, Physella acuta, Phys. heterostropha, Costatella integra) із застосуванням сучасних методів багатовимірної статистики. 3'ясовано, що кількісні ознаки статевої системи можуть бути використані для ідентифікації видів.

Ключові слова: Physinae, статева система, багатовимірна статистика, копулятивний апарат.

Постановка наукової проблеми та ії значення. Пухирчикові - це відносно невеличка родина прісноводних черевоногих легеневих молюсків (80 видів), які мають не дексіотропну, а лейотропну черепашку. Підродина Рhysinae відома з юри й розповсюджена здебільшого в Північній Америці та на півночі Євразії.

Щодо кількості видів пухирчикових у світовій фауні, а також розповсюджених у прісних водоймах Європи, достеменних відомостей на сьогодні поки що немає. Це зумовлено розбіжністю поглядів, по-перше, на систематику цієї родини й, по-друге, на таксономічний статус чималої кількості їі представників. А причина цього полягає в тому, що дослідники «східної» малакологічної школи (Я. І. Старобогатов і його послідовники) та сучасні нам західноєвропейські малакологи відзна-

(C) Гарлінська А., 2015 
Рівні флуктуючої асиметрії парних меристичних ознак представників іхтіофауни р. Устя (створ №1)

\begin{tabular}{|c|c|c|c|c|c|c|c|c|c|c|c|c|c|c|c|c|c|c|c|}
\hline \multirow{2}{*}{\multicolumn{2}{|c|}{$\begin{array}{l}\text { Ознака } \\
\text { Значення* }\end{array}$}} & \multicolumn{3}{|c|}{$\begin{array}{c}\text { Верховодка } \\
(\mathrm{n}=27 \text { екз. })\end{array}$} & \multicolumn{3}{|c|}{$\begin{array}{c}\text { Плітка } \\
(\mathrm{n}=24 \text { екз. }) \\
\end{array}$} & \multicolumn{3}{|c|}{$\begin{array}{c}\begin{array}{c}\text { Краснопірка } \\
(\mathbf{n}=25 \text { екз. })\end{array} \\
\end{array}$} & \multicolumn{3}{|c|}{$\begin{array}{l}\text { Окунь річковий } \\
\text { (n= 21 екз.) }\end{array}$} & \multicolumn{3}{|c|}{$\begin{array}{c}\text { Карась сріблстий } \\
(\mathrm{n}=26 \text { екз.) }\end{array}$} & \multicolumn{3}{|c|}{$\begin{array}{c}\text { Лящ } \\
(\mathrm{n}=\mathbf{2 3} \text { екз. })\end{array}$} \\
\hline & & $\mathbf{R}$ & $\mathbf{L}$ & $\mathbf{A}$ & $\mathbf{R}$ & $\mathbf{L}$ & $\mathbf{A}$ & $\mathbf{R}$ & $\mathbf{L}$ & $\mathbf{A}$ & $\mathbf{R}$ & $\mathbf{L}$ & $\mathbf{A}$ & $\mathbf{R}$ & $\mathbf{L}$ & $\mathbf{A}$ & $\mathbf{R}$ & $\mathbf{L}$ & $\mathbf{A}$ \\
\hline \multirow{3}{*}{$P$} & $\mathrm{M}$ & 10,6 & 10,7 & \multirow{3}{*}{15} & 16,7 & 16,5 & \multirow{3}{*}{11} & 10,5 & 10,6 & \multirow{3}{*}{8} & 13,8 & 13,7 & \multirow{3}{*}{10} & 12,8 & 12,8 & \multirow{3}{*}{7} & 16,5 & 16,6 & \multirow{3}{*}{11} \\
\hline & $\pm \mathrm{m}$ & 0,62 & 0,64 & & 0,57 & 0,72 & & $\begin{array}{l}0,59 \\
\end{array}$ & 0,5 & & 0,51 & 0,48 & & 0,37 & 0,40 & & 0,51 & 0,51 & \\
\hline & $\mathrm{P} \leq$ & 0,05 & 0,05 & & 0,05 & 0,05 & & 0,05 & 0,05 & & - & 0,05 & & 0,01 & 0,01 & & 0,05 & 0,05 & \\
\hline \multirow{3}{*}{ V } & $\mathrm{M}$ & 8,2 & 8,0 & \multirow{3}{*}{11} & 8,8 & 8,6 & \multirow{3}{*}{7} & 13,7 & 13,6 & \multirow{3}{*}{9} & 10,6 & 10,6 & \multirow{3}{*}{7} & 11,8 & 11,8 & \multirow{3}{*}{10} & 8,8 & 8,7 & \multirow{3}{*}{9} \\
\hline & $\pm \mathrm{m}$ & 0,43 & 0,61 & & 0,44 & 0,5 & & 0,48 & 0,49 & & 0,51 & 0,49 & & 0,40 & 0,40 & & 0,42 & 0,45 & \\
\hline & $\mathrm{P} \leq$ & 0,05 & 0,05 & & 0,05 & 0,05 & & 0,05 & 0,05 & & 0,05 & 0,05 & & 0,01 & 0,01 & & 0,01 & 0,05 & \\
\hline \multirow{3}{*}{$s p . b r$} & $\mathrm{M}$ & 45,2 & 45,3 & \multirow{3}{*}{21} & 11,4 & 11,3 & \multirow{3}{*}{14} & 45,4 & 45,0 & \multirow{3}{*}{19} & 51,3 & 51,2 & & 52,1 & 52,1 & & 23,3 & 23,2 & \\
\hline & $\pm \mathrm{m}$ & 0,82 & 0,71 & & 0,65 & 0,64 & & 0,7 & 0,76 & & 0,66 & 0,7 & 14 & 0,61 & 0,59 & 7 & 0,77 & 0,72 & 15 \\
\hline & $\mathrm{P} \leq$ & 0,05 & 0,05 & & 0,05 & 0,05 & & 0,05 & 0,05 & & 0,05 & 0,05 & & 0,05 & 0,05 & & 0,05 & 0,05 & \\
\hline & $\mathrm{M}$ & 9,7 & 9,6 & & 2,8 & 2,8 & & 9,8 & 9,6 & & 11,8 & 11,6 & & 12,8 & 12,8 & & 2,7 & 2,7 & \\
\hline f.br. & $\pm \mathrm{m}$ & 0,5 & 0,6 & 13 & 0,42 & 0,44 & 9 & 0,44 & 0,49 & 9 & 0,40 & 0,50 & 8 & 0,37 & 0,40 & 5 & 0,47 & 0,49 & 11 \\
\hline & $\mathrm{P} \leq$ & 0,05 & 0,05 & & 0,01 & 0,05 & & 0,05 & 0,05 & & 0,01 & 0,05 & & 0,01 & 0,01 & & 0,05 & 0,05 & \\
\hline & $\mathrm{M}$ & 45,6 & 45,6 & & 41,7 & 41,7 & & 42,8 & 42,7 & & 67,8 & 67,7 & & 40,9 & 40,9 & & 52,8 & 52,7 & \\
\hline$j j$ & $\pm \mathrm{m}$ & 0,57 & 0,49 & 11 & 0,48 & 0,46 & 12 & 0,5 & 0,56 & 12 & 0,4 & 0,46 & 6 & 0,33 & 0,27 & 3 & 0,39 & 0,47 & 9 \\
\hline & $\mathrm{P} \leq$ & 0,05 & 0,05 & & 0,05 & 0,05 & & - & 0,05 & & 0,01 & 0,05 & & - & - & & 0,05 & 0,05 & \\
\hline & $\bar{M}$ & 18,7 & 18,7 & & 40,8 & 40,8 & & 37,7 & 37,8 & & 60,7 & 60,6 & & 38,9 & 38,9 & & 52,7 & 52,7 & \\
\hline$j j_{c k}$ & $\pm \mathrm{m}$ & 0,53 & 0,47 & 5 & 0,44 & 0,42 & 11 & 0,48 & 0,44 & 10 & 0,46 & 0,50 & 8 & 0,19 & 0,33 & 4 & 0,49 & 0,45 & 7 \\
\hline & $\mathrm{P} \leq$ & 0,05 & 0,05 & & 0,05 & 0,01 & & 0,05 & 0,05 & & 0,05 & 0,05 & & - & - & & 0,05 & 0,05 & \\
\hline & $\bar{M}$ & 10,7 & 10,9 & & 6,9 & 6,9 & & 9,8 & 9,7 & & 7,9 & 7,9 & & $\begin{array}{l}8,9 \\
\end{array}$ & 8,9 & & 9,0 & 9,0 & \\
\hline$s q u \cdot{ }_{\cdot}$ & $\pm \mathrm{m}$ & 0,45 & 0,36 & 5 & 0,34 & 0,2 & 4 & 0,44 & 0,48 & 8 & 0,22 & 0,36 & 4 & 0,19 & 0,27 & 3 & 0,0 & 0,0 & 0 \\
\hline & $\mathrm{P} \leq$ & 0,05 & 0,05 & & - & - & & 0,05 & 0,05 & & - & - & & - & - & & - & - & \\
\hline & $\mathrm{M}$ & 3,8 & 3,7 & & 3,9 & 3,9 & & 3,9 & 3,8 & & 4,9 & 4,9 & & 4,8 & 4,8 & & 4,0 & 4,0 & \\
\hline$s q u_{\cdot 2}$ & $\pm \mathrm{m}$ & 0,4 & 0,48 & 5 & 0,2 & 0,3 & 3 & 0,28 & 0,37 & 7 & 0,30 & 0,30 & 5 & 0,37 & 0,37 & 2 & 0,0 & 0,0 & 0 \\
\hline & $\mathrm{P} \leq$ & 0,05 & 0,05 & & - & - & & - & 0,01 & & - & - & & 0,01 & 0,01 & & - & - & \\
\hline & $\mathrm{M}$ & 11,8 & 11,7 & & 9,9 & 9,8 & & 12,9 & 12,9 & & 11,9 & 11,9 & & 11,8 & 11,8 & & 12,9 & 12,8 & \\
\hline squ.pl & $\pm \mathrm{m}$ & 0,40 & 0,47 & 3 & 0,3 & 0,4 & 2 & 0,29 & 0,38 & 5 & 0,32 & 0,27 & 5 & 0,37 & 0,37 & 0 & 0,28 & 0,38 & 6 \\
\hline & $\mathrm{P} \leq$ & 0,05 & 0,05 & & - & 0,01 & & - & 0,01 & & - & - & & 0,01 & 0,01 & & - & 0,01 & \\
\hline
\end{tabular}

*Примітка. $\mathrm{R}$ - величина ознак із правої сторони тіла риб; L - величина ознак із лівої сторони тіла риб; А - кількість асиметричних проявів ознаки у вибірці; М - середня величина ознаки для вибірки, см; $\pm \mathrm{m}$ - середньоквадратичне відхилення; Р $\leq-$ рівень помилки за критерієм Стьюдента [10]. 
Рівні флуктуючої асиметрії парних меристичних ознак представників іхтіофауни р. Устя (створ № 2)

\begin{tabular}{|c|c|c|c|c|c|c|c|c|c|c|c|c|c|c|c|c|c|c|c|}
\hline \multirow{2}{*}{\multicolumn{2}{|c|}{ Ознака }} & \multicolumn{3}{|c|}{$\begin{array}{c}\text { Верховодка } \\
\text { (n= 27 екз.) }\end{array}$} & \multicolumn{3}{|c|}{$\begin{array}{c}\text { Плітка } \\
\text { (n= 22 екз.) }\end{array}$} & \multicolumn{3}{|c|}{$\begin{array}{c}\text { Краснопірка } \\
(\mathbf{n}=35 \text { екз.) }\end{array}$} & \multicolumn{3}{|c|}{$\begin{array}{c}\text { Окунь річковий } \\
\text { (n= 32 екз.) }\end{array}$} & \multicolumn{3}{|c|}{$\begin{array}{c}\text { Карась сріблстий } \\
(\mathrm{n}=\mathbf{3 8} \text { екз.) }\end{array}$} & \multicolumn{3}{|c|}{$\begin{array}{c}\text { Лящ } \\
\text { (n= 23 екз.) }\end{array}$} \\
\hline & & $\mathbf{R}$ & $\mathbf{L}$ & $\mathbf{A}$ & $\mathbf{R}$ & $\mathbf{L}$ & $\mathbf{A}$ & $\mathbf{R}$ & $\mathbf{L}$ & $\mathbf{A}$ & $\mathbf{R}$ & $\mathbf{L}$ & $\mathbf{A}$ & $\mathbf{R}$ & $\mathbf{L}$ & $\mathbf{A}$ & $\mathbf{R}$ & $\mathbf{L}$ & $\mathbf{A}$ \\
\hline \multirow{3}{*}{$P$} & $\mathrm{M}$ & 10,9 & 11,0 & \multirow{3}{*}{12} & 16,4 & 16,8 & \multirow{3}{*}{18} & 10,4 & 10,5 & \multirow{3}{*}{21} & 13,5 & 13,3 & \multirow{3}{*}{21} & 12,6 & 12,6 & \multirow{3}{*}{14} & 16,7 & 16,7 & \multirow{3}{*}{13} \\
\hline & $\pm \mathrm{m}$ & 0,62 & 0,48 & & 0,53 & 0,57 & & 0,8 & 0,66 & & 0,62 & 0,65 & & 0,5 & 0,49 & & 0,54 & 0,45 & \\
\hline & $\mathrm{P} \leq$ & 0,05 & 0,05 & & 0,05 & 0,05 & & 0,05 & 0,05 & & 0,05 & 0,05 & & 0,05 & 0,05 & & 0,01 & 0,05 & \\
\hline \multirow{3}{*}{ V } & $\mathrm{M}$ & 8,4 & 8,4 & \multirow{3}{*}{13} & 8,9 & 8,6 & \multirow{3}{*}{14} & 13,5 & 13,5 & \multirow{3}{*}{18} & 10,8 & 10,9 & \multirow{3}{*}{19} & 11,7 & 11,6 & \multirow{3}{*}{15} & 8,6 & 8,7 & \multirow{3}{*}{11} \\
\hline & $\pm \mathrm{m}$ & 0,75 & 0,69 & & 0,51 & 0,47 & & 0,74 & 0,66 & & 0,91 & 0,91 & & 0,49 & 0,46 & & 0,59 & 0,56 & \\
\hline & $\mathrm{P} \leq$ & 0,05 & 0,05 & & 0,05 & 0,05 & & 0,05 & 0,05 & & 0,05 & 0,05 & & 0,01 & - & & 0,05 & 0,01 & \\
\hline \multirow{3}{*}{$s p . b r}$. & $\mathrm{M}$ & 45,4 & 45,2 & \multirow{3}{*}{21} & 11,4 & 11,1 & \multirow{3}{*}{26} & 45,3 & 45,5 & \multirow{3}{*}{23} & 52,2 & 52,3 & & 52,2 & 52,1 & & 24,3 & 24,2 & \\
\hline & $\pm \mathrm{m}$ & 0,75 & 0,89 & & 0,91 & 0,67 & & 0,77 & 0,66 & & 0,83 & 0,96 & 22 & 0,79 & 0,76 & 16 & 0,82 & 0,67 & 16 \\
\hline & $\mathrm{P} \leq$ & 0,05 & 0,05 & & 0,05 & 0,05 & & 0,05 & 0,05 & & 0,05 & 0,05 & & 0,05 & 0,05 & & 0,05 & 0,05 & \\
\hline & $\mathrm{M}$ & 13,9 & 14,0 & & 2,4 & 2,5 & & 9,7 & 9,7 & & 11,8 & 11,8 & & 12,7 & 12,7 & & 12,9 & 12,8 & \\
\hline f.br. & $\pm \mathrm{m}$ & 0,27 & 0,0 & 3 & 0,53 & 0,58 & 16 & 0,46 & 0,47 & 5 & 0,42 & 0,42 & 4 & 0,45 & 0,45 & 8 & 0,34 & 0,39 & 7 \\
\hline & $\mathrm{P} \leq$ & 0,05 & 0,05 & & 0,05 & 0,05 & & 0,05 & 0,05 & & 0,05 & 0,05 & & - & - & & - & 0,01 & \\
\hline & $\bar{M}$ & 46,8 & 46,7 & & 41,7 & 41,6 & & 45,7 & 45,7 & & 41,6 & 41,7 & & 40,5 & 40,6 & & 38,7 & 38,6 & \\
\hline$i j$ & $\pm \mathrm{m}$ & 0,51 & 0,53 & 17 & 0,45 & 0,43 & 15 & 0,73 & 0,70 & 17 & 0,49 & 0,52 & 17 & 0,51 & 0,50 & 17 & 0,54 & 0,51 & 10 \\
\hline & $\mathrm{P} \leq$ & 0,05 & 0,05 & & 0,05 & 0,05 & & 0,05 & 0,05 & & 0,05 & 0,05 & & 0,01 & 0,01 & & 0,01 & 0,01 & \\
\hline & $\mathrm{M}$ & 44,5 & 44,5 & & 40,4 & 40,8 & & 44,6 & 44,6 & & 39,8 & 39,8 & & 38,7 & 38,6 & & 38,7 & 38,5 & \\
\hline$j j_{c k}$ & $\pm \mathrm{m}$ & 0,7 & 0,6 & 19 & 0,44 & 0,49 & 14 & 0,61 & 0,69 & 16 & 0,49 & 0,44 & 13 & 0,48 & 0,49 & 7 & 0,57 & 0,59 & 12 \\
\hline & $\mathrm{P} \leq$ & 0,05 & 0,05 & & 0,05 & 0,05 & & 0,05 & 0,05 & & 0,05 & 0,05 & & 0,01 & 0,01 & & 0,05 & 0,05 & \\
\hline & $\mathrm{M}$ & 10,9 & 10,9 & & 6,7 & 6,9 & & 10,6 & 10,6 & & 8,8 & 8,8 & & $\begin{array}{l}8,7 \\
\end{array}$ & 8,7 & & $\begin{array}{l}8,7 \\
\end{array}$ & 8,9 & \\
\hline$s q u_{.1}$ & $\pm \mathrm{m}$ & 0,32 & 0,27 & 8 & 0,34 & 0,40 & 12 & 0,6 & 0,55 & 7 & 0,4 & 0,44 & 8 & 0,52 & 0,46 & 9 & 0,56 & 0,29 & 7 \\
\hline & $\mathrm{P} \leq$ & 0,05 & 0,05 & & 0,05 & 0,05 & & 0,55 & 0,55 & & 0,05 & 0,05 & & - & - & & 0,01 & - & \\
\hline & $\mathrm{M}$ & 3,8 & 3,8 & & 3,9 & 3,8 & & 3,6 & 3,7 & & 5,8 & 5,7 & & 4,7 & 4,7 & & 3,9 & 3,9 & \\
\hline$s q u_{2}$ & $\pm \mathrm{m}$ & 0,42 & 0,58 & 9 & 0,34 & 0,37 & 8 & 0,6 & 0,59 & 9 & 0,51 & 0,46 & 9 & 0,45 & 0,48 & 5 & 0,29 & 0,34 & 6 \\
\hline & $\mathrm{P} \leq$ & 0,05 & 0,05 & & 0,05 & 0,05 & & 0,05 & 0,05 & & 0,05 & 0,05 & & - & - & & - & - & \\
\hline & $\bar{M}$ & 10,7 & 10,7 & & 10,8 & 10,9 & & 10,7 & 10,7 & & 12,7 & 12,8 & & 11,7 & 11,7 & & 12,8 & 12,8 & \\
\hline squ.pl & $\pm \mathrm{m}$ & 0,73 & 0,45 & 10 & 0,35 & 0,32 & 7 & 0,46 & 0,51 & 6 & 0,54 & 0,44 & 10 & 0,48 & 0,46 & 4 & 0,39 & 0,42 & 9 \\
\hline & $\mathrm{P} \leq$ & 0,05 & 0,05 & & 0,05 & 0,05 & & 0,05 & 0,05 & & 0,05 & 0,05 & & - & - & & 0,01 & 0,01 & \\
\hline
\end{tabular}

*Примітка. $\mathrm{R}$ - величина ознак із правої сторони тіла риб; $\mathrm{L}$ - величина ознак із лівої сторони тіла риб; А - кількість асиметричних проявів ознаки у вибірці; М - середня величина ознаки для вибірки, см; $\pm \mathrm{m}$ - середньоквадратичне відхилення; Р $\leq-$ рівень помилки за критерієм Стьюдента [10]. 
Рівні флуктуючої асиметрії парних меристичних ознак представників іхтіофауни р. Устя (створ №3)

\begin{tabular}{|c|c|c|c|c|c|c|c|c|c|c|c|c|c|c|c|c|c|c|c|}
\hline \multirow{2}{*}{\multicolumn{2}{|c|}{$\begin{array}{l}\text { Ознаки } \\
\text { Значення* }\end{array}$}} & \multicolumn{3}{|c|}{$\begin{array}{c}\begin{array}{c}\text { Верховодка } \\
(\mathrm{n}=25 \text { екз. })\end{array} \\
\end{array}$} & \multicolumn{3}{|c|}{$\begin{array}{c}\text { Плітка } \\
(\mathbf{n}=32 \text { екз. })\end{array}$} & \multicolumn{3}{|c|}{$\begin{array}{c}\text { Краснопірка } \\
(\mathrm{n}=\text { екз. })\end{array}$} & \multicolumn{3}{|c|}{$\begin{array}{c}\text { Окунь річковий } \\
(\mathrm{n}=\text { екз. })\end{array}$} & \multicolumn{3}{|c|}{$\begin{array}{c}\begin{array}{c}\text { Карась сріблстий } \\
\text { (n= екз.) }\end{array} \\
\end{array}$} & \multicolumn{3}{|c|}{$\begin{array}{c}\text { Лящ } \\
(\mathrm{n}=\text { екз.) }\end{array}$} \\
\hline & & $\mathbf{R}$ & $\mathbf{L}$ & $\mathbf{A}$ & $\mathbf{R}$ & $\mathbf{L}$ & $\mathbf{A}$ & $\mathbf{R}$ & $\mathbf{L}$ & $\mathbf{A}$ & $\mathbf{R}$ & $\mathbf{L}$ & $\mathbf{A}$ & $\mathbf{R}$ & $\mathbf{L}$ & $\mathbf{A}$ & $\mathbf{R}$ & $\mathbf{L}$ & $\mathbf{A}$ \\
\hline \multirow{3}{*}{$P$} & $\mathrm{M}$ & 10,6 & 10,8 & \multirow{3}{*}{9} & 16,6 & 16,5 & \multirow{3}{*}{20} & 10,7 & 10,6 & \multirow{3}{*}{17} & 13,7 & 13,7 & \multirow{3}{*}{15} & 12,9 & 12,9 & \multirow{3}{*}{8} & 16,9 & 16,8 & \multirow{3}{*}{7} \\
\hline & $\pm \mathrm{m}$ & 0,49 & 0,44 & & 0,56 & 0,57 & & 0,45 & 0,49 & & 0,48 & 0,46 & & 0,36 & 0,36 & & 0,29 & 0,43 & \\
\hline & $\mathrm{P} \leq$ & 0,05 & 0,05 & & 0,05 & 0,05 & & 0,05 & 0,05 & & 0,05 & 0,05 & & 0,01 & 0,01 & & - & 0,01 & \\
\hline \multirow{3}{*}{$V$} & $\bar{M}$ & 7,6 & 7,6 & \multirow{3}{*}{10} & 8,7 & 8,6 & \multirow{3}{*}{12} & 13,7 & 13,6 & \multirow{3}{*}{11} & 10,8 & 10,5 & \multirow{3}{*}{14} & 11,9 & 11,8 & \multirow{3}{*}{4} & 8,9 & 8,9 & \multirow{3}{*}{5} \\
\hline & $\pm \mathrm{m}$ & 0,49 & 0,49 & & 0,48 & 0,49 & & 0,48 & 0,49 & & 0,44 & 0,51 & & 0,36 & 0,42 & & 0,29 & 0,32 & \\
\hline & $\mathrm{P} \leq$ & 0,05 & 0,05 & & 0,05 & 0,05 & & 0,05 & 0,05 & & 0,05 & 0,05 & & 0,01 & 0,05 & & - & - & \\
\hline \multirow{3}{*}{ sp.br. } & $\mathrm{M}$ & 45,0 & 44,8 & \multirow{3}{*}{22} & 11,1 & 11,3 & \multirow{3}{*}{24} & 45,2 & 45,4 & \multirow{3}{*}{21} & 51,1 & 51,0 & & 52,3 & 52,3 & & 23,8 & 23,9 & \\
\hline & $\pm \mathrm{m}$ & 0,89 & 0,8 & & 0,82 & 0,74 & & 0,82 & 0,72 & & 0,83 & 0,75 & 17 & 0,81 & 0,71 & 13 & 0,5 & 0,24 & 10 \\
\hline & $\mathrm{P} \leq$ & 0,05 & 0,05 & & 0,05 & 0,05 & & 0,05 & 0,05 & & 0,05 & 0,05 & & 0,05 & 0,05 & & 0,05 & 0,05 & \\
\hline & $\mathrm{M}$ & 9,5 & 9,6 & & 2,6 & 2,5 & & 10,5 & 10,5 & & 11,5 & 11,7 & & 12,7 & 12,6 & & 2,9 & 2,8 & \\
\hline$f \cdot b r$. & $\pm \mathrm{m}$ & 0,59 & 0,58 & 18 & 0,55 & 0,57 & 14 & 0,57 & 0,64 & 16 & 0,51 & 0,48 & 11 & 0,48 & 0,50 & 10 & 0,29 & 0,43 & 7 \\
\hline & $\mathrm{P} \leq$ & 0,05 & 0,05 & & 0,05 & 0,05 & & 0,05 & 0,05 & & 0,05 & 0,05 & & 0,05 & 0,05 & & - & 0,01 & \\
\hline & $\mathrm{M}$ & 45,5 & 45,7 & & 41,8 & 41,6 & & 37,8 & 37,6 & & 68,7 & 68,6 & & 40,8 & 40,8 & & 52,9 & 52,9 & \\
\hline$j j$ & $\pm \mathrm{m}$ & 0,65 & 0,48 & 17 & 0,42 & 0,49 & 18 & 0,37 & 0,49 & 16 & 0,46 & 0,50 & 5 & 0,39 & 0,39 & 9 & 0,35 & 0,35 & 6 \\
\hline & $\mathrm{P} \leq$ & 0,05 & 0,05 & & 0,05 & 0,05 & & 0,01 & 0,05 & & 0,05 & 0,05 & & 0,01 & 0,01 & & - & - & \\
\hline & $\bar{M}$ & 18,7 & 18,7 & & 40,8 & 40,6 & & 42,8 & 42,8 & & 60,8 & 60,7 & & 38,9 & 38,8 & & 52,8 & 52,8 & \\
\hline$j j_{c k}$ & $\pm \mathrm{m}$ & 0,46 & 0,46 & 15 & 0,44 & 0,49 & 18 & 0,37 & 0,43 & 12 & 0,44 & 0,48 & 8 & 0,36 & 0,42 & 8 & 0,4 & 0,43 & 4 \\
\hline & $\mathrm{P} \leq$ & 0,05 & 0,05 & & 0,05 & 0,05 & & 0,01 & 0,05 & & 0,05 & 0,05 & & 0,01 & 0,05 & & 0,01 & 0,01 & \\
\hline & $\mathrm{M}$ & 10,9 & 10,8 & & 6,9 & 6,8 & & 9,9 & 9,9 & & 7,8 & 7,8 & & 9,0 & 8,9 & & 8,9 & 9,0 & \\
\hline$s q u_{.1}$ & $\pm \mathrm{m}$ & 0,2 & 0,44 & 7 & 0,34 & 0,40 & 10 & 0,25 & 0,34 & 4 & 0,38 & 0,38 & 4 & 0,0 & 0,32 & 4 & 0,29 & 0,0 & 2 \\
\hline & $\mathrm{P} \leq$ & - & 0,05 & & 0,05 & 0,05 & & - & 0,01 & & 0,01 & 0,01 & & - & - & & - & - & \\
\hline & $\bar{M}$ & 4,0 & 3,8 & & 3,8 & 3,9 & & 3,9 & 3,9 & & 4,9 & 4,9 & & 4,9 & 4,9 & & 3,9 & 3,9 & \\
\hline$s q u_{2}$ & $\pm \mathrm{m}$ & 0,0 & 0,41 & 5 & 0,37 & 0,34 & 7 & 0,25 & 0,3 & 5 & 0,20 & 0,28 & 3 & 0,32 & 0,2 & 3 & 0,21 & 0,35 & 2 \\
\hline & $\mathrm{P} \leq$ & - & 0,01 & & 0,05 & 0,05 & & - & - & & - & - & & - & - & & - & - & \\
\hline & $M$ & 12,0 & 11,9 & & 10,8 & 10,9 & & 12,9 & 12,9 & & 11,8 & 11,7 & & 11,9 & 11,9 & & 12,9 & 12,9 & \\
\hline squ.pl & $\pm \mathrm{m}$ & 0,0 & 0,28 & 2 & 0,37 & 0,30 & 7 & 0,25 & 0,3 & 3 & 0,42 & 0,46 & 2 & 0,19 & 0,26 & 3 & 0,29 & 0,29 & 2 \\
\hline & $\mathrm{P} \leq$ & - & - & & 0,05 & 0,05 & & - & - & & 0,05 & 0,05 & & - & - & & - & - & \\
\hline
\end{tabular}

*Примітка. $\mathrm{R}$ - величина ознак із правої сторони тіла риб; L - величина ознак із лівої сторони тіла риб; А - кількість асиметричних проявів ознаки у вибірці; M - середня величина ознаки для вибірки, $c м ; \pm \mathrm{m}$ - середньоквадратичне відхилення; Р $\leq-$ рівень помилки за критерієм Стьюдента [10]. 